\title{
Political Agency, Election Quality, and Corruption
}

\author{
Miguel R. Rueda, Emory University \\ Nelson A. Ruiz, University of Oxford
}

How does electoral manipulation affect elected officials' willingness to satisfy their constituents? Although the literature has highlighted the role of elections as mechanisms of accountability, we do not know how elections whose integrity is compromised influence elected officials' actions in office. We present a model of accountability that allows for electoral manipulation and derive three results: (i) rent extraction increases with the level of electoral manipulation, (ii) the value of holding office is positively related to rent extraction for high values of office, and (iii) electoral manipulation increases with the value of office. Using a fuzzy regression discontinuity design that exploits rules determining the sizes of polling stations in Colombia, we estimate a positive causal effect of vote buying on the likelihood of the election winner being sanctioned for violating the disciplinary code of public officials. Consistent with the theory, we find that higher values of office are not linked to fewer sanctions but are associated with more vote buying.

lections are generally thought of as mechanisms of political accountability. They can be seen as sanctioning devices used to punish underperforming politicians or as filters that help voters separate the "good" leaders from the rest (Bernard, Przeworksi, and Stokes 1999; Fearon 1999). The desire to hold public office, paired with elections, should push politicians to deliver the outcomes that voters want. Yet, corruption, underprovision of public goods, and lack of responsiveness by elected officials are all common in many democracies. Why? A large literature has studied the role of voters' informational constraints and electoral institutions in determining deviations from beneficial policies. ${ }^{1}$ This article shifts the focus to a pervasive feature of elections around the world that has not received the same attention: electoral manipulation.

The link between electoral manipulation and the unwillingness of politicians to act in favor of their constituents is exemplified by the recent electoral history of La Guajira, a state in northern Colombia. Since 2000, there have been six consecutive elected governors who have been prosecuted and found guilty on charges of embezzlement of public resources, irregularities in granting public contracts, and even murder (see García 2016; Semana 2013). Four of them had previously held public office as mayors or governors, and they all belong to two political movements whose electoral support in the region remained steady despite the scandals. Elections are competitive, but they are neither clean nor fair. In fact, La Guajira has one of the highest numbers of reports of electoral irregularities in Colombia, and two of these governors have been investigated on electoral manipulation charges as well (see Arenas 2014; El Heraldo 2013). Why have the prospects of continuing a political career not pushed politicians to serve their constituencies better? Has the ability to engage in electoral irregularities encouraged elected officials to engage in administrative corruption and other illegal acts?

We first formulate a simple formal model to study these questions. In the model, an incumbent facing an election chooses a quantity of rents to take for herself from public resources and selects a level of effort to invest in electoral manipulation. If electoral manipulation is successful in influencing the outcome of the election, the incumbent has an electoral advantage regardless of past levels of rent extraction. If not, voters are free to vote for the incumbent or the challenger. In particular, voters observe the level of public goods-determined by the incumbent's unobserved

Miguel R. Rueda (miguel.rueda@emory.edu) is an assistant professor in the Department of Political Science at Emory University, Atlanta, GA 30322. Nelson A. Ruiz (nelson.ruiz@politics.ox.ac.uk) is a lecturer in comparative politics in the Department of Politics and International Relations at the University of Oxford, Oxford OX1 3UQ, United Kingdom, and adjunct professor of economics, Universidad del Rosario, Bogotá, Colombia.

Data and supporting materials necessary to reproduce the numerical results in the article are available in the JOP Dataverse (https://dataverse.harvard.edu /dataverse/jop). An online appendix with supplementary material is available at https://doi.org/10.1086/708243.

1. For recent surveys of the literature, see Ashworth (2012) and DeVries and Solaz (2017).

The Journal of Politics, volume 82, number 4. Published online July 8, 2020. https://doi.org/10.1086/708243 (C) 2020 by the Southern Political Science Association. All rights reserved. 0022-3816/2020/8204-0006 $\$ 10.00$ 
capabilities and by the resources left after rent extractionand decide whether to reelect the incumbent. The model generates three main findings: (i) rent extraction increases with electoral manipulation, (ii) electoral manipulation increases with the value of office, and (iii) the value of holding public office is positively related to rent extraction for high office values.

The theory captures a basic intuition that links electoral malpractice with the responsiveness of public officials. Electoral manipulation reduces politicians' incentives to satisfy voters because it diminishes the influence of policy outcomes on the choices voters make at the ballot box. This observation has an important implication for how the value of holding public office shapes incumbents' actions during their tenure. A more valuable office pushes the incumbent to try to win the election by any means, including by engaging in electoral manipulation. This electoral manipulation shrinks the likelihood of the election being determined by voters' perceptions about the incumbent on the basis of past performance. Consequently, high office values can reduce the willingness of incumbents to satisfy voters.

We explore the relationship between rent extraction and electoral manipulation using data on disciplinary sanctions of mayors and reports of vote buying in elections in Colombia during 2003-11. Colombia is a particularly interesting case to test our theory on given its long history with democratic institutions, free press, and weak party system that reduce the explanatory power of alternative theories of electoral accountability. The disciplinary sanctions in our data are imposed by the Office of the Inspector General (Procuraduría General de la Nación) most commonly for embezzlement of public resources, violations of contracting laws, and other actions linked to administrative corruption but not for electoral irregularities. For the measure of electoral manipulation, we use citizens' reports of vote buying, the most widespread form of electoral malpractice in Colombia. ${ }^{2}$

We find that mayors in elections with more reports of vote buying are significantly more likely to be prosecuted, found guilty, and removed from office for corruption during their terms. Moreover, we find that there is a robust positive correlation between two proxies for value of office (the salaries of mayors and discretionary revenues of the municipality) with reports of vote buying and that these measures of value of office are not negatively correlated with disciplinary sanctions. The three results are consistent with the main mechanism emphasized by our theory: in places where elected office is highly valued, politicians will more often try to win

2. We define vote buying as the distribution of excludable material benefits to individuals in exchange for their votes. elections by any means, including electoral manipulation, which weakens the disciplinary effects of elections.

While finding a positive association between disciplinary sanctions and vote buying is consistent with the main prediction of the theory, there are alternative mechanisms that could account for this finding. Incumbent politicians could use public resources to finance their vote buying efforts (De La O 2015; Singer 2009), and disillusioned voters in corrupt environments might be more open to clientelism (Cleary and Stokes 2006). Similarly, voters might be less likely to report vote buying and cases of administrative corruption because they distrust the institutions that investigate these practices. To address reverse causality and omitted variable concerns and others related to mismeasurement of electoral and administrative corruption, we implement an instrumental variables (IV) strategy that exploits differences in polling station sizes as plausible sources of exogenous variation in vote buying. We do this informed by the literature on clientelism that predicts more vote buying in places where parties have access to more disaggregated election results (Gingerich and Medina 2013; Larreguy, Marshall, and Querubin 2016; Rueda 2015, 2017; Smith and Bueno de Mesquita 2012). In Colombia, those are the municipalities with smaller polling stations, as vote totals are published at the polling station level. The IV estimates are also in line with the theoretical expectations.

While we are able to control for a large set of municipality characteristics that make the validity of the exclusion restriction more plausible, we additionally check the robustness of these results with a fuzzy regression discontinuity (RD) design. In Colombia, most polling stations are capped at 400 registered voters. If there are more registered voters in the precinct, a new polling station is installed. The fuzzy RD compares municipalities whose number of registered voters is right below and above a multiple of 400 registered voters. The municipalities right below would tend to have a larger average polling station size, while the ones above would tend to have smaller polling stations on average. The first group of municipalities should have less expected vote buying than the second, but they should be similar in all other determinants of mayors' disciplinary violations as well as in factors driving misreporting of these violations or vote buying. We find that a $10 \%$ increase in reports of vote buying increases the probability of the mayor being prosecuted for violations of the disciplinary code during her tenure by 4.8 percentage points and that of her being found guilty and removed from office by 3.6 and 2.6 percentage points, respectively.

Our article is part of the literature on electoral accountability and corruption. The key question of this body of work is what factors provide elected officials with incentives to follow voters' wishes. Voters' information about the incumbents 
(Chong et al. 2015; Ferraz and Finan 2008; Winters and Weitz-Shapiro 2013), heterogeneities within the electorate (Anduiza, Gallego, and Munoz 2013; Klašnja 2017; WeitzShapiro and Winters 2016), and institutional characteristics like term limits and ballot structure (Ferraz and Finan 2011; Gingerich 2013; Klašnja and Titiunik 2017; Kunicová and Rose-Ackerman 2005) have been identified as determinants of politicians' willingness to deviate from citizens' desired policies. Our theory is most closely related to work that focuses on the relationship between the value of holding public office and electoral accountability. Unlike traditional models (e.g., Ferejohn 1986; Persson and Tabellini 2000), our theory does not predict that an incumbent will be more interested in pursuing the best policies when she values the office more. Others have generated similar predictions and have found mixed empirical support for the positive effects of a higher value of office on selection or elected officials' effort (e.g., Besley 2004; Brollo et al. 2013; Fisman et al. 2015; Gagliarducci and Nannicini 2013). Brollo et al. (2013), for example, hypothesize that an increase in resources available to the government-which can be directly tied to the value of holding office - gives the incumbent more room to grab rents without disappointing rational voters. We contribute to this literature by offering a theory that places electoral manipulation as a key factor explaining why higher values of office do not always improve elected officials' performance.

More generally, the link between the quality of the electoral process and accountability has received less attention, and, with few exceptions (De La O 2015; Nyblade and Reed 2008; Singer 2009), the literature has often lumped together practices of administrative corruption and electoral malfeasance. De La O (2015) and Singer (2009) study perceptions of corruption and their relationship with vote buying and find a positive association. Both studies argue that corruption generates resources used for clientelistic campaigns. Nyblade and Reed (2008) study the determinants of administrative corruption and clientelism in Japan but not the causal links between them. This article provides a new theory of electoral accountability when electoral manipulation is common and presents evidence of a positive causal effect of vote buying on administrative corruption.

Finally, this article contributes to the literature that studies the effects of electoral manipulation (Cantu 2016; Gingerich 2014; Hidalgo and Nichter 2016; Imai, Park, and Greene 2015; Simpser 2012; Vicente 2013). The focus of this work has been the estimation of "first order" effects of electoral manipulation on voting choices and turnout. Our results complement these findings by showing that the quality of elections is an important determinant of actions taken by elected officials during their terms.

\section{A SIMPLE MODEL}

In this section, we follow Persson and Tabellini (2000) and adapt their career concerns framework to allow for electoral manipulation during the campaign. Consider a game in which there are two time periods denoted by $t \in\{1,2\}$. In each of these periods, a politician in office chooses rents, $r_{t} \in[0, \bar{r}]$. We can think of $r_{t}$ as the diversion of public resources for private use. We assume that the total resources available to the politician, $R$, cannot be completely exhausted by rents, and so $\bar{r} \in(0, R)$.

When choosing the rents, the politician faces the budget constraint, $g_{t}=\eta\left(R-r_{t}\right)$, where $g_{t}$ denotes the level of public good provision and $\eta$ the competence of the politician. According to this expression, a competent politician is able to provide more public goods using the same resources than one whose $\eta$ is lower. We assume that $\eta$ is distributed uniformly over $[1-(1 / 2 \xi), 1+(1 / 2 \xi)]$. Once $\eta$ is realized, it remains as a feature of the politician.

An election is held in the first period. Before the election, the incumbent politician chooses a level of effort to invest in electoral manipulation, $m \in[0,1]$. Since electoral manipulation is not always effective, we assume that with probability $m$ electoral manipulation influences the results of the election. In this case, the incumbent will win the election with probability $(1 / 2)+\chi$ (with $\chi \in(0,1 / 2]$ ). A positive $\chi$ captures the electoral advantage that successful manipulation efforts give to the incumbent. ${ }^{3}$ With probability $1-m$, however, election results are not influenced by manipulation efforts, in which case the electorate is free to vote as they please. Engaging in electoral irregularities can be costly. These costs are captured by a function $c$ that is twice continuously differentiable and has strictly positive first and second derivatives for nonzero values of $m$.

Apart from setting the second period rents, the politician who wins the election gets a payoff of $E$, which represents ego-rents, wages, or other perks of holding office. The payoffs over the two periods of the incumbent are then $r_{1}-$ $c(m)+p\left(E+r_{2}\right)$, where $p$ denotes the probability of the incumbent winning the election. Voters care about the level of public goods received in both periods.

The timing of events is as follows: (1) the incumbent chooses the level of rents and effort invested in electoral manipulation. (2) The value of $\eta$, the ability of the incumbent, is realized, and voters observe the policy outcome, $g_{1}$, but neither the incumbent's ability nor the level of extracted

3. When $\chi \leq 0$ the model collapses to the standard electoral accountability model, which gives the incumbent a probability of winning of $1 / 2$ in equilibrium. 
rents, $r_{1}$. (3) Elections take place. (4) The winner of the election chooses the rents in the second period.

There are a number of simplifying assumptions in the model: $\eta$ is realized after rents and levels of manipulation are chosen, only the incumbent engages in manipulation, electoral manipulation is not financed with public resources, and there is no horizontal accountability (institutions guarding the integrity of elections) deterring the incumbent from engaging in electoral manipulation. These assumptions capture a scenario in which a politician in her first term does not know with certainty how effective her efforts at providing public goods will be and in which incumbents have logistical advantages when engaging in electoral manipulation. They are also consistent with environments where institutions in charge of guarding the elections are inefficient or captured by the incumbent. In appendix A (apps. A-G are available online), we explore how the findings from the baseline setting change once we relax each of these assumptions. We discuss these differences below.

\section{THEORETICAL RESULTS}

In the second period, nothing prevents the politician who wins the election from extracting the maximum level of rents, so $r_{2}=\bar{r}$ regardless of what happened before. This implies that voters receive $g_{2}=\eta(R-\bar{r})$. Since this level of public goods is increasing in ability, voters are better off electing the candidate they perceive to be the most competent. Given that voters observe the level of public goods at the time of the election, they try to infer the competence of the incumbent on the basis of this information and vote for her when they believe the incumbent is more competent than the average challenger. When manipulation does influence the election, however, the incumbent has an electoral advantage regardless of the observed provision of public goods.

The next result describes the relationship between equilibrium electoral manipulation and rents and presents comparative statics. The proof is in appendix A.

Proposition 1. The following statements characterize an interior equilibrium in the electoral manipulation game.

1. There is a positive relationship between the equilibrium levels of electoral manipulation, $m^{\star}$, and the rents in period one, $r^{*}$.

2. There is a positive relationship between the value of office, $E+\bar{r}$, and equilibrium rents, $r^{\star}$, for high values of office. Moreover, depending on the shape of the cost function, $c$, this relationship might be positive for all values of office.
3. Equilibrium levels of manipulation, $m^{*}$, are strictly increasing in the value of holding office, $E+\bar{r}$, and the advantage given by successful manipulation, $\chi$.

4. The probability of the incumbent winning is strictly increasing in the electoral manipulation efforts, $m^{*}$, and the advantage given by successful manipulation, $\chi$.

When electoral manipulation increases, it is more likely that the level of public goods will not influence the election results. This reduces the negative electoral consequences of extracting rents in the first period. With high manipulation, a low provision of public goods gives voters reason to vote for a challenger, but their votes are effectively canceled by the electoral irregularities. As a result, rent accumulation becomes an attractive option for the incumbent. One observable implication of this finding is that electoral manipulation should have a causal effect on actions that favor the incumbent at the expense of the public.

In standard accountability models (e.g., Besley 2007; Ferejohn 1986; Persson and Tabellini 2000), the desire to obtain the prize associated with winning pushes politicians to do what the public wants. The second and third statements of the proposition indicate that this is no longer true with electoral irregularities. In this model, a more valuable office gives the incumbent incentives to win by any means, including breaking the electoral rules. An incumbent with a greater interest in being elected would increase electoral manipulation efforts, which in turn reduces the need to please an electorate that rewards low rent extraction.

The last statement of the proposition tells us that electoral manipulation gives an electoral advantage to the politician who engages in it. The empirical literature has already provided evidence consistent with this theoretical finding. In particular, turnout and vote buying do seem to be associated with higher vote shares for the manipulators (Cantu 2016; Larreguy et al. 2016; Vicente 2013). In the rest of the article, we focus on evaluating the empirical evidence relating to the first three statements of the proposition.

If we allow the incumbent's challenger to exert effort to manipulate election results, we find similar substantive conclusions regarding the relationships between overall manipulation and rents, manipulation and value of office, and value of office and rents. However, in a symmetric interior equilibrium, both parties manipulate, which causes their manipulation efforts to cancel each other. More manipulation from both parties still incentivizes rent seeking by diminishing the likelihood of a free vote, but it does not increase the probability of 
winning, as now the manipulation from one party invites a similar response from the other.

The baseline model studies the impact of any type of electoral manipulation that gives an advantage to the incumbent on electoral accountability. In our empirical application, however, we focus on vote buying, which has two distinctive features: first, the bribes received by the voters increase the utility of the recipient and, second, vote buying sometimes is financed with public resources. In appendix A, we micro-found the advantage given to the incumbent by buying votes by modeling the direct impact of bribes on the utility of voters and show that the main predictions from the baseline model hold. The same is true if vote buying is financed with public resources. In this case, however, the positive relationships between electoral manipulation and rents and between office values and rents are both weaker than in the baseline model. The reason for this is that as manipulation increases, this takes away resources for both rents and public goods, forcing the incumbent to moderate rent extraction to be able to convey competence.

A similar logic applies if we account for an independent judiciary that could punish an incumbent for engaging in electoral manipulation. With this type of horizontal accountability, electoral manipulation still encourages rent extraction, but given that it can induce a punishment, we observe less manipulation and weaker positive links between value of office and manipulation and the value of office and rents. Finally, we can reach similar conclusions to those of the baseline model in a setting with discrete types of politicians and a discrete action space where the incumbent learns her type at the beginning of the game. In an equilibrium in which "public minded" politicians never manipulate or extract rents and where "opportunistic" ones do so depending on cost of manipulation and potential available rents, low-cost electoral manipulation pushes opportunistic types to engage in corruption. ${ }^{4}$

\section{COLOMBIAN INSTITUTIONS AND ELECTORAL CONTEXT}

Before describing our empirical analysis, we highlight characteristics of the Colombian electoral environment and institutions that are important for our empirical strategy. Historically, Colombia has had a strong central government run either by the Conservative party or the Liberal party. In the eighties and nineties, however, several reforms were enacted to decentralize the country. One of the most influential reforms came in 1986 when elected mayors were introduced in municipalities. Following these changes, the 1991 constitutional

4. A more detailed discussion of each of these extensions is in app. A. reform increased decentralization of social spending. One major goal of the reforms was to boost the responsiveness of local officials to their constituents.

Currently, mayors are in charge of designing the budget and implementing an annual development plan in municipalities. Although most municipalities receive transfers from the central government that are tied to specific expenses, mayors have discretion over an average of $26 \%$ of all local spending. ${ }^{5}$ Most of the discretionary resources come from property tax revenues (Martínez 2016). These resources are used for the provision of education, health insurance, water, and sanitation projects.

Public officials in Colombia, and mayors in particular, are overseen by the Office of the Inspector General. This institution initiates, pursues, and rules on investigations into public officials for violations of their disciplinary code. The possible sanctions include fines, removal from office, or even bans from future public employment. Most sanctions are related to administrative mismanagement, corruption, and the violation of procurement and contracting norms. Importantly for our empirical strategy, the Office of the Inspector General does not investigate violations of the electoral law, which are the responsibility of the attorney general (Fiscalía General de la Nación).

The Office of the Inspector General does not report to the judiciary, the legislative bodies, or the executive and is considered an independent entity. The inspector general is appointed by the Senate for a four-year term and chosen from a group of three candidates nominated by the president, Supreme Court, and Council of State. Investigations can start on the basis of information presented by citizens or the watchdog agency, Contraloría General. In the period of analysis, regional contralores - those who audit mayorswere appointed by department assemblies and municipal councils from triads nominated by superior tribunals (Tribunales Superiores de Distrito y de lo Contencioso Administrativo). ${ }^{6}$ Regional inspectors general oversee investigations against mayors and are appointed directly by the inspector general. These arrangements limit the influence of mayors on cases in which they are involved.

\section{ELECTIONS}

Regional elections have been held every four years since 2003. In each election, members of municipal councils, department assemblies, municipality mayors, and governors

5. Data are from 2004-7 incumbency period.

6. Officials who were elected in the previous year cannot be considered in these triads. See Articles 272 and 276 of the Colombian constitution. 
are elected. Mayors and governors are elected by plurality, and members of legislative bodies are elected by party-list proportional representation.

Colombia uses the Australian ballot (el tarjetón). The 1991 reform eliminated the old system in which citizens could only vote using ballots that were distributed by the parties, making the current ballot effectively secret. The most disaggregated electoral results available are those of polling stations. These are published on the website of the National Registrar's Office (Registraduría Nacional del Estado Civil) shortly after the elections.

The size and location of the polling stations are determined by the National Registrar's Office. The Registrar's Office defines the maximum number of voters allowed to vote per polling station in the months before an election. The maximum size varies according to the type of precinct and its location. For the years 2003 and 2007, the size of most polling stations was 400 voters. $^{7}$

Importantly, there is no consecutive reelection for mayors, but many continue their political careers by running for Congress, governorships, or municipal councils. Some of them also run for mayor of the same municipality in later years. A famous example among Colombians is that of former congressman Enrique Peñaloza, who unsuccessfully ran for mayor of Bogotá, in 1991 and 1994, before being elected to the office during his third attempt in 1997. Peñaloza then ran and lost two more times, in 2007 and 2010, before regaining office in 2015 . More generally, $62 \%$ of mayors in 1988 had participated in elections after their terms, some of them successfully. ${ }^{8}$ Former mayors constituted $14 \%$ of all members of Congress in 2010,22\% of governors in 2011, and $16 \%$ of mayors in 2015 . This indicates that, consistent with the model, mayors often rely on their constituencies for future electoral support. ${ }^{9}$

\section{DATA}

One immediate challenge when empirically examining the predictions of our theory is that it is not possible to observe the true levels of rent extraction or electoral manipulation. Even in weak institutional settings, corrupt candidates still want to hide their illegal actions. Moreover, in a competitive

7. Special voting centers like Corferias in Bogotá can take more voters, but our data do not allow us to know the fraction of polling stations for which the special rules apply. See National Registrar's resolution 1883 of 2007.

8. In the sample of mayors in 2003 and $2007,37.79 \%$ ran in the future, and $25.71 \%$ ran for mayor of the same municipality.

9. For evidence of electoral accountability driven by future political aspirations without immediate reelection, see Micozzi (2014). political setting, false claims of illegal activities against rivals could overstate the level of illegality.

We address these problems of measurement error using two strategies. The first is to use various proxies for rent extraction. Finding consistently similar evidence across multiple indicators should increase the confidence that the results are not driven by measurement problems specific to any of them. The second strategy employs IV regressions that, under plausible assumptions, allow us to account for potential biases caused by measurement error in electoral manipulation and sanctions.

In the models that explore the link between electoral malpractice and mayors' actions, we first use as a dependent variable an indicator of whether the mayor of a municipality was prosecuted for a violation of norms that govern public officials during her term. For each of these prosecution cases, we have information on the outcome of the investigation. This allows us to create an indicator of whether the mayor was declared guilty. The last dependent variable used in these models is an indicator of whether the mayor was removed from office once declared guilty. The data, collected by Martínez (2016), cover 2004-11 and were originally taken from news bulletins published by the Office of the Inspector General of Colombia on its website. We also collect information from the Inspector General's Office to determine whether the elected mayors had a previous history of sanctions.

An advantage of the guilty indicator over the prosecution one is that it has less contamination from false accusations of corruption. This is because, generally, to reach a guilty ruling, more evidence is required than to start a prosecution. While the impeachment indicator is superior to the guilty one for the same reasons, it ignores less serious offenses that can also be affected by electoral accountability pressures. This suggests that the guilty indicator more closely captures our theoretical concept of rents while being relatively more robust to false positives than prosecutions.

In addition to the three variables of disciplinary sanctions from the Office of the Inspector General, we check the robustness of the results by using a cross-section of municipalities for which indexes of the risk of administrative corruption from Transparency International Colombia are available. This information is summarized in the Transparency Index, in which higher values denote less risk of corruption. An advantage of this measure relative to the disciplinary sanctions information is that it does not suffer from measurement error generated by citizens' misreporting. A limitation, however, is that we only have this measure for a cross-section of $252 \mathrm{mu}-$ nicipalities that responded in 2005 and 2006 to the questionnaires sent by Transparency International used to compute the index. 
Our measure of electoral manipulation is the number of reports of vote buying incidents filed at regional offices of the attorney general. These data contain the number of reports from every municipality for the two elections covered in the analysis, 2003 and 2007. Vote buying is the most common form of manipulation in Colombian regional elections. According to the Latin American Public Opinion Project in 2003 and 2007, 16.44\% of respondents reported having been offered bribes in exchange for their votes, while only $1.75 \%$ and $1.14 \%$ reported having been pressured into abstaining or threatened to vote for a given candidate. ${ }^{10}$ Moreover, relative to ballot stuffing, tampering with registration lists, or other irregularities related to the administration of elections, citizens can more easily observe vote buying.

The last two variables of interest are measures of the value of office. The first is the maximum salary that a mayor of a given municipality can earn, which is determined according to fixed institutional rules by the municipality population and the amount of nonearmarked revenues. ${ }^{11}$ The second is the amount of these nonearmarked or discretionary revenues. The resources over which the mayor has discretion increase the mayor's visibility and influence.

Violations of the disciplinary code are common in the data. In $24.22 \%$ of municipality period observations, the mayor was prosecuted. The chance of a mayor being found guilty is $16.36 \%$ and that of being removed from office is $9.46 \%$. There is also a high probability of being found guilty, conditional on having been prosecuted. A mayor who is prosecuted is found guilty $67.53 \%$ of the time. Furthermore, one who is found guilty has a $57.82 \%$ chance of having committed a serious offense that justified her removal from office. ${ }^{12}$

The average number of reports of vote buying in the municipality per 1,000 people is 0.027 . This is a low rate if we compare it to the percentage of respondents of the Latin American Public Opinion survey approached by brokers (16.44\%). Informal conversations with election monitors, candidates, and party operatives indicate that citizens might not want to report vote buying incidents because it is time consuming and the reports are not anonymous. In what follows, we present our baseline results, discuss how our inferences are affected by misreporting of vote buying, and offer a strategy to address these problems.

10. A $10 \%$ increase in vote buying reports made to the Attorney General's Office is associated with a 0.12 increase in the fraction of respondents in Latin American Public Opinion Project receiving vote buying offers.

11. Law 617 of 2000 defines different categories for municipalities according to population and discretionary revenues. Categories also determine limits for operating expenses and certain central government transfers.

12. Appendix $G$ presents summary statistics of all variables used in the analysis.

\section{DISCIPLINARY SANCTIONS AND VOTE BUYING}

Recall that in the model, the possibility of engaging in electoral irregularities during the election induces greater rent extraction. If current levels of manipulation give politicians an indication of how much elections can be manipulated in the future, we would expect to find a causal effect of observed electoral irregularities on violations of the disciplinary code for public officials. To test this, we estimate equations of the form

$$
s_{i, t}=b_{i, t} \gamma+\mathbf{x}_{i, t-1} \beta+\zeta_{i}+\varepsilon_{i, t},
$$

where $s_{i, t}$ is a measure of disciplinary sanctions of the mayor in municipality $i$ committed for violations in the period following the election of year $t$ and $b_{i, t}$ is the logged number of vote buying reports. The vector $\mathbf{x}_{i, t-1}$ includes the average margin of victory of all races, an indicator of the presence of guerrillas or paramilitary forces, the share of local revenues in total revenues of the municipality, the share of the population living in rural areas, an indicator of whether the mayor had any disciplinary sanctions at the time of the campaign, and the share of underperforming schools based on the national standardized ICFES (Instituto Colombiano para el Fomento de la Educación Superior) test results. ${ }^{13}$ Given that vote buying is measured in logged number or reports, controls include the logged population. All controls are lagged or measured in the previous election. For some specifications, we include municipality fixed effects denoted by $\zeta_{i}$. Since most of our dependent variables are dichotomous, we provide estimates for nonlinear models as robustness checks in appendix G. All standard errors are clustered at the municipality level.

Table 1 presents the results for the disciplinary sanctions models. We see that there is a positive association between the reports of vote buying and the three sanctions variables. According to model 1, an increase of $10 \%$ in the number of vote buying reports is associated with an increase of 0.77 percentage points $(0.077 / 100 \times 10)$ in the probability of the mayor being prosecuted. We see a similar pattern when the dependent variable is whether the mayor was declared guilty. When it is an indicator of removal (model 5), the coefficient is still positive but smaller, and it is only significant at the $11 \%$ level.

It is important to note that the dependent variable does not include sanctions for violations of the electoral rules and that separate institutions are in charge of investigating sanctions of the disciplinary code and electoral irregularities, which rules out that the previous findings are driven by the way our corruption proxies are measured. It is possible, however, that the positive association between the likelihood

13. For more detailed definitions of control variables, see app. B. 
Table 1. Disciplinary Sanctions and Vote Buying

\begin{tabular}{|c|c|c|c|c|c|c|}
\hline & \multicolumn{2}{|c|}{ Prosecuted } & \multicolumn{2}{|c|}{ Guilty } & \multicolumn{2}{|c|}{ Removed } \\
\hline & (1) & (2) & (3) & (4) & (5) & (6) \\
\hline Vote buying & $\begin{array}{l}.077^{\star * *} \\
(.029)\end{array}$ & $\begin{array}{c}.074^{\star} \\
(.043)\end{array}$ & $\begin{array}{l}.068^{\star *} \\
(.027)\end{array}$ & $\begin{array}{c}.071^{*} \\
(.039)\end{array}$ & $\begin{array}{c}.036 \\
(.022)\end{array}$ & $\begin{array}{l}.055^{\star} \\
(.032)\end{array}$ \\
\hline Fixed effects & No & Yes & No & Yes & No & Yes \\
\hline
\end{tabular}

Note. Ordinary least squares coefficients, with robust standard errors clustered at the municipality level in parentheses. All models include baseline controls. Fixed effects denotes models with municipality fixed effects. $\mathrm{Mu}-$ nicipalities $=1,086$; observations $=2,072$.

${ }^{*} p<.1$.

${ }^{* *} p<.05$.

${ }^{* * *} p<.01$.

of sanctions and vote buying is explained by omitted variables and not by the weakening of electoral accountability pressures as our theory suggests. Models 2, 4, and 6 add municipality fixed effects as a first strategy to address these concerns. These models account for unobserved confounders that are invariant over the period of analysis, like institutional quality and an entrenched corruption culture. We see that the coefficient on vote buying is still positive for all the dependent variables examined, and its magnitude is slightly larger for the model of removal from office.

\section{Endogenous vote buying}

The previous results just give us the first approximation to the relationship between vote buying and administrative corruption and should be interpreted with caution. There are potential time-varying unobserved variables that could still explain the relationship of interest. For example, there might be "bad types" of candidates who have an advantage at manipulating elections and who are more likely to engage in administrative corruption once they are elected. Similarly, the previous estimates could be biased upward if mayors engage in corruption and use public resources to finance vote buying efforts or if voters become more open to clientelism in corrupt environments.

In addition to these omitted variable and reverse causality concerns, there are other potential challenges related to our measures of vote buying and corruption. Ordinary least squares (OLS) estimates of the effect of vote buying would be understated if there is more vote buying in municipalities where violations of the disciplinary code are not investigated. This could happen if citizens are disillusioned with the fraudulent elections and are therefore less likely to report mayors' illegal actions or if the mayors of those municipalities are better at avoiding investigations. Yet, it is also possible that voters tend to underreport vote buying and administrative corruption where they perceive institutions to be ineffective. Furthermore, some regions might lack the capacity to enforce laws to protect against administrative and electoral corruption. In these last two cases, the estimated coefficient on vote buying would be biased upward.

We undertake two separate IV strategies that address concerns associated with measurement error, potential confounders, and reverse causality. For an IV approach to give us sensible estimates, we need to find sources of exogenous variation in vote buying that are not related to factors driving citizens' misreporting or other causes of mismeasurement. Moreover, the instrument should not affect violations of the disciplinary code through channels other than vote buying, and it must be a strong predictor of actual vote buying once we partial out the effects of other controls. Appendix $\mathrm{C}$ derives an expression for the large sample biases of OLS under the conditions of interest and shows that a valid instrument that is also orthogonal to errors of measurement of vote buying and administrative corruption allows for consistent estimation of the effect of interest.

The first instrument we propose is the average number of citizens voting in a polling station in a municipality. The literature offers two explanations for why the size of polling stations determines the incidence of vote buying in secret ballot elections. The first highlights how small polling stations and more disaggregated electoral results give more fine-grained information about voting behavior that helps to enforce vote buying contracts (Gingerich and Medina 2013; Rueda 2015, 2017; Smith and Bueno de Mesquita 2012). The second explanation hinges on the actions taken by parties to prevent their brokers from shirking or misallocating vote buying resources. When there are many polling stations (smaller average polling stations), parties have more information regarding the performance of brokers who mobilize voters in the area (Larreguy et al. 2016). In this way, more polling stations facilitate a solution to the moral hazard problem faced by parties who try to control unaligned brokers.

One concern with using polling station size as an instrument of vote buying is that places where polling stations are small tend to be rural areas where voters are less educated and where underreporting of any crimes might be common. This would violate the exclusion restriction and also the orthogonality of the instrument to the measurement error in vote buying. A similar concern is that in places where illegal armed groups operate, voters would fear reporting any irregularities. To account for this, we control for lagged measures of education quality, population size, presence of armed actors, and the percentage of the population living in rural areas. The results of this IV approach are very similar whether or not we control for these regressors. We additionally control for the 
main determinant of the size of the polling station, which is the logged number of registered voters in the previous election.

Table 2 presents the results in columns $1-3$. We see that the estimated coefficient on vote buying is large and still significant. A $10 \%$ increase in vote buying reports raises the likelihood of the mayor being prosecuted by 7.4 percentage points. This represents a large increase in the magnitude of the effect relative to the OLS estimates, suggesting that a smaller rate of investigations where vote buying is common and where disciplinary violations occurred was biasing the previous estimates downward. ${ }^{14}$ There is a similar effect on the guilty indicator. As for removal from office, the effect is smaller but still substantively important. The table shows that, consistent with the theories of clientelism summarized above, there is a strong negative relationship between the average size of the polling station and the reporting of vote buying.

\section{Discontinuities in polling station sizes and vote buying}

An alternative, and perhaps more robust, identification strategy uses a fuzzy $\mathrm{RD}$ design that relies on variation in the average size of the polling stations induced by an institutional rule that caps the sizes of polling stations. The institutional rule predicts sharp reductions in the average size of polling stations every time the number of registered voters reaches a multiple of the maximum number of citizens (400) allowed to vote. This is explained because a new polling station needs to be added, reducing the average size of polling stations in that municipality. These reductions should affect the levels of vote buying and are used to estimate this variable's causal effect on corruption. This is done by using the average size of polling stations predicted by the institutional rule as an instrument for vote buying levels.

The intuition for this strategy is simple. A municipality whose number of registered voters is right above the threshold that determines the number of polling stations should be similar to one whose registered number of voters is right below. ${ }^{15}$ The difference is that the first one would have smaller polling stations on average and, because of this, more vote buying, while the second one would have larger polling stations on average and less vote buying. This indicates that there should be sharp changes in the levels of vote buying above and below the thresholds determined by the sizes of polling stations, but the sources of measurement error in vote buying and all determinants of disciplinary violations (or the factors behind misreporting of those violations) are unlikely to experience such discontinuities.

14. Appendix $\mathrm{C}$ shows that OLS estimates are also attenuated.

15. Below we confirm that these municipalities are indeed similar.
The dashed line in figure 1 shows the predicted size of the average polling station in 2007 if all the registered voters in the municipality were divided equally among the stations with sizes limited by the regulation, Rule-based size $_{i, t}$. It is computed as

Rule-based size ${ }_{i, t}=\frac{\text { Registered }_{i, t}}{\operatorname{int}\left(\left(\text { Registered }_{i, t}-1\right) / \text { Maxsize }_{t}\right)+1}$,

where Maxsize $_{t}$ is the maximum size imposed by the regulation and $\operatorname{int}(\cdot)$ is a function that returns the integer part of the number. The solid lines in figure 1 represent the actual size of the average polling stations in the data. The figure reflects the expected discontinuities at every multiple of 400 explained by the need to include additional polling stations. The function represented by the dashed line serves as the instrument for vote buying. As with any $\mathrm{RD}$ design, identification relies on the ability to distinguish the relationship between the dependent variable (sanctions for disciplinary violations) and the discontinuous function from the effect of smooth functions of the running variable (registered voters). Because of this, we include as a control the logged number of registered voters. Note that the logged number of registered voters has a slope that closely mirrors that of $\log$ (Ruled-based size $_{i, t}$ ) for municipalities with hundreds or more registered voters. Once the trend effects of registered voters are controlled for, there should be no need to hold any other regressors fixed, as only the variation around the discontinuities is being used for identification (Angrist and Lavy 1999). ${ }^{16}$

Columns 4-9 in table 2 report the fuzzy RD results. Here, our estimand corresponds to the weighted average across cutoff points of the local average effects at each of these cutoffs (Cattaneo et al. 2016). Models in columns 4, 6, and 8 use the full sample. We see that the effect of vote buying is smaller but substantively important and more precisely estimated than in the regressions that used the actual size of polling stations as instruments. Columns 5, 7, and 9 restrict the sample to municipalities with polling stations that are within 40 voters of a discontinuity point. Not surprisingly, with this small sample size, the precision of our estimates as well as the instrument's explanatory power in the first stage is reduced, but importantly, the estimates are positive and stable. In appendix $G$ we show that, in fact, the estimated coefficients are stable for multiple bandwidths around the discontinuity points when using the indicators of guilty and removed from office.

To test the validity of the fuzzy RD design, we carried out a number of checks. One concern is that corrupt candidates

16. Results are robust to using vote buying in levels while controlling for a piecewise linear function whose slope coincides with the slope of (2) out of the discontinuity points. 


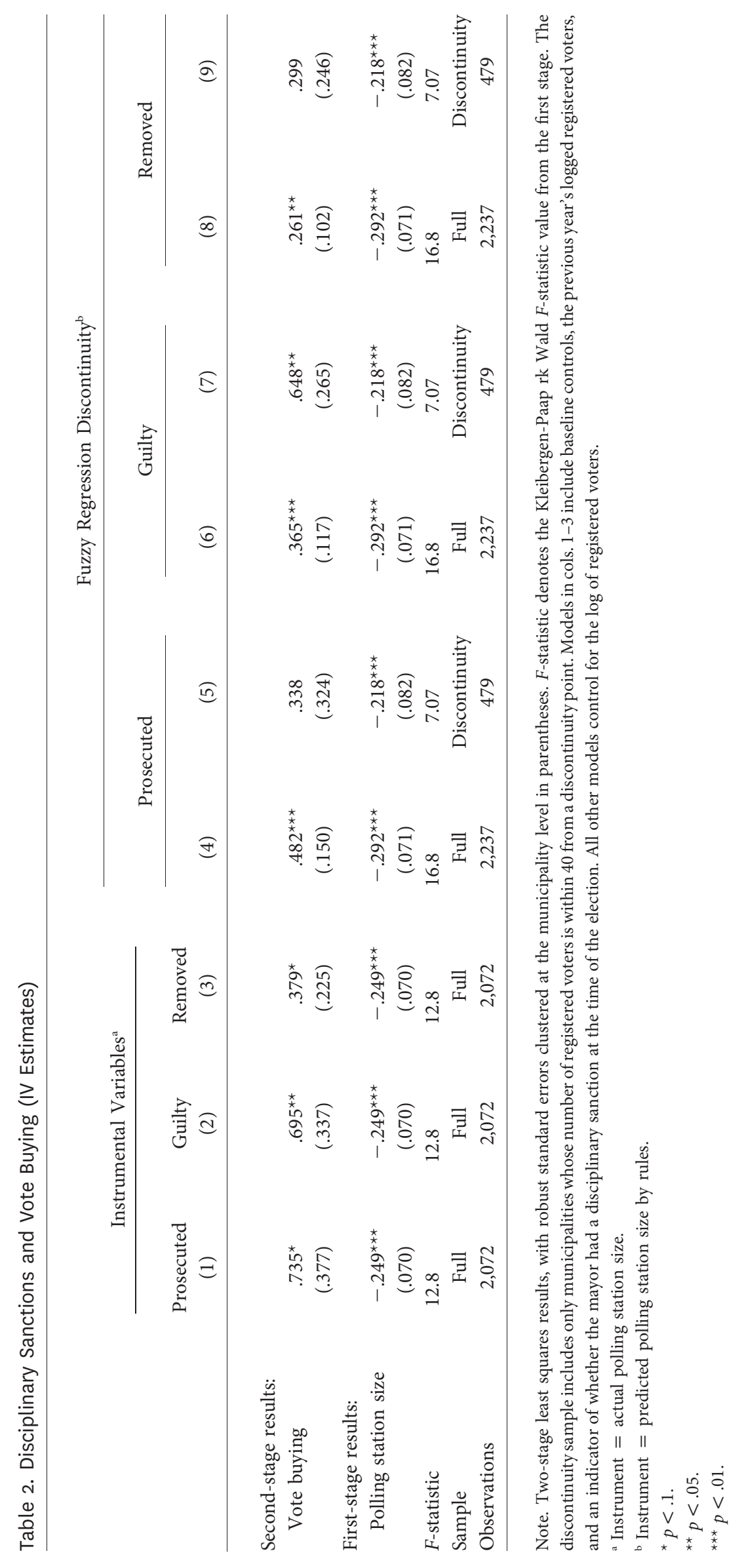




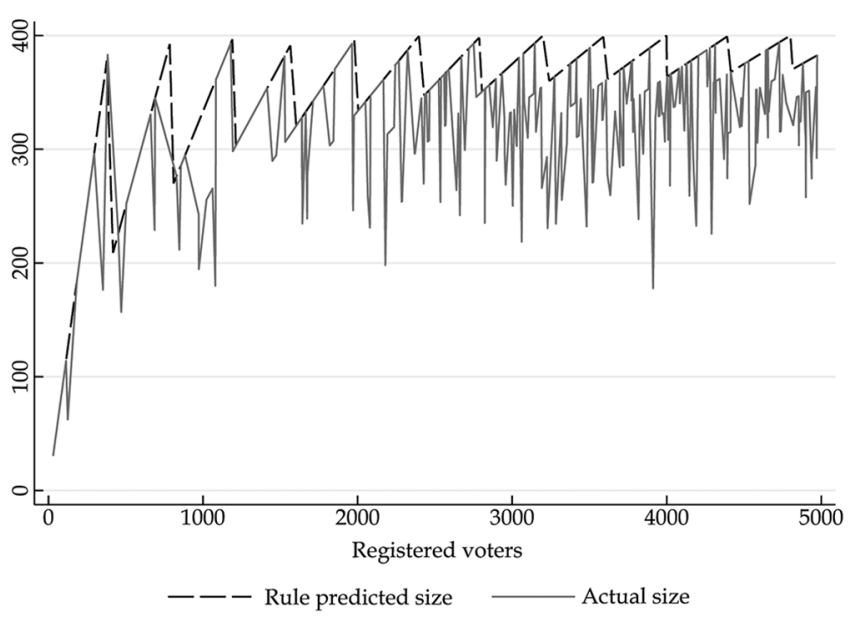

Figure 1. Polling station sizes and registered voters in 2007

engaging in manipulation may exploit the rule capping polling station sizes to their advantage by artificially inflating the number of registered voters to have more and, on average, smaller polling stations. In this case, the exogeneity of the predicted size of a polling station by the institutional rule around the cutoff would be called into question. Although possible, this type of manipulation is hard to carry out, as politicians would have to make very good predictions of the actual number of registered voters in order to know how many voters are needed to add new polling stations. Nevertheless, to see whether this concern is important in practice, we examined the distribution of the number of registered voters looking for differences below and above the cutoffs. If politicians exploit the rule and change the average size of polling stations, we should see a higher frequency of municipalities that are right above the discontinuity points. Appendix D reports results of two sorting tests indicating that this is not a feature of the data.

We also examine whether there are effects of having smaller average polling stations on the observed characteristics of the municipalities (other than vote buying) near the discontinuities. If there were, this would cast doubt on the assumption that the municipalities below and above these thresholds are similar in all aspects related to corruption or measurement of our variables of interest. Appendix D shows that there are no significant differences in observed characteristics between municipalities above and below the cutoffs.

Finally, we check that mayors of municipalities below and above the discontinuity thresholds do not have systematic differences in their observed characteristics. In particular, there are no statistically significant differences in their likelihood of being former mayors, their previous sanctions, or their involvement in lawsuits. These results, together with the fact that candidates cannot easily exploit the rules determin- ing polling station sizes, suggest that our findings are not driven by selection effects. That is, the fraction of "bad politicians" is likely the same in municipalities right above and below the thresholds that determine the average size of a polling station.

\section{VALUE OF OFFICE}

Our theory offers two additional observable implications derived from proposition 1 (pts. 2 and 3) regarding the relationships between value of office, manipulation, and violations of the disciplinary code of public officials. The first is that we should observe a positive association between the value of office and vote buying. Table 3 presents the results of linear models in which the dependent variable is the logged number of vote buying reports. ${ }^{17}$ The models in columns 1 and 2 have as the explanatory variable the salary of mayors. These specifications also control for the full set of baseline controls used in the disciplinary sanctions models. The coefficient on salary is positive in both models, but it is not precisely estimated once municipality fixed effects are added to the model. The smaller insignificant fixed effects estimate is explained by the fact the salary is almost invariant over time within a municipality, given that it is determined by rules according to ranges of population size and discretionary revenues.

To circumvent this limitation with salaries, we use the logged discretionary revenues in the municipality as an alternative measure of value of office. This measure is particularly close to our theoretical concept of value of office that captures not only the ego rents and perks from office $(E)$ but also the maximum level of rents that can be taken by the politician $(\bar{r})$. Moreover, Colombian mayors, especially in large municipalities, have more discretion over the allocation of public resources. It is this ability to sign government contracts that motivates many candidates to run.

We see in table 3 that, consistent with the model's prediction, there is a positive and significant coefficient on discretionary revenue in models with and without municipality effects. The most conservative estimate from the model in column 4 indicates that an increase of $10 \%$ in discretionary resources in the municipality is associated with a $0.3 \%$ increase in the number of reports of vote buying (close to a standard deviation of the dependent variable).

The second observable implication regarding value of office is that, in the presence of electoral manipulation, we should not expect to find a monotonic negative relationship between measures of value of office and levels of corruption.

17. We include 2011 observations, as vote buying reports and value of office measures are available for this year. OLS results with baseline controls are robust to excluding this year. 
Table 3. Vote Buying and Value of Office

(1)

(2)

(3)

Discretionary revenue

$.048^{* * *} \quad .031^{\star}$

$(.015)$

$(.018)$

Mayor's salary

$.028^{* *}$

.009

$(.007)$

$(.012)$

Fixed effects

Observations

Municipalities

No

Yes

$3,105 \quad 3,105$

No

Yes

Note. Ordinary least squares coefficients, with robust standard errors clustered at the municipality level in parentheses. Dependent variable $=\ln$ (Vote Buying +1$)$. All models include baseline controls and an indicator of whether the mayor had previous disciplinary sanctions at the time of the election. Fixed effects denotes models with municipality fixed effects.

${ }^{*} p<.1$.

${ }^{* *} p<.05$.

${ }^{* * *} p<.01$

Table 4 shows that, if anything, there seems to be a positive relationship between values of office and the likelihood of the mayor being prosecuted, declared guilty, or removed from office in a sample of municipalities where vote buying was reported.

Given that the relationship between value of office and corruption predicted by the model can be nonmonotonic, as proposition 1 part 2 indicates, we check whether the results hold for a less restrictive characterization of this relationship by using a semiparametric estimator. Appendix G presents results from a double residual semiparametric regression showing that the relationship between vote buying and our measures of rents is not monotonically decreasing and actually has a positive slope for most values of vote buying.

It is important to note that we need to be cautious when giving an interpretation to the results in this section, as the econometric analysis is carried out under the assumption that our proxies for value of office are exogenous. A concern is that corrupt politicians who are good at organizing clientelistic campaigns seek to run in places where the mayor has discretion over substantial resources. The previous results, however, also control for the number of sanctions against the elected mayor in that municipality at the time of the election. Finally, the results are not driven by higher values of office generating more competition in an election, which in turn brings more reports of corruption or vote buying. We control for the average margin of victory in all regional previous elections.

\section{FUTURE POLITICAL ASPIRATIONS AND TRANSPARENCY INDEX}

Our theory explores the incentives of mayors for whom reputational concerns are important. A concern with the baseline results of the link between electoral manipulation and disciplinary sanctions is that they could be driven by mayors without future political aspirations. These mayors might care less about voters' electoral responses to corruption and might want to be elected to extract rents. We gather information on whether the mayors in the sample end up being candidates in subsequent elections. We focus on the mayors who have to appeal to the same voters that they served for their support in the next election where they are allowed to run, which are

Table 4. Disciplinary Sanctions and Value of Office

\begin{tabular}{|c|c|c|c|c|c|c|}
\hline & \multicolumn{2}{|c|}{ Prosecuted } & \multicolumn{2}{|c|}{ Guilty } & \multicolumn{2}{|c|}{ Removed } \\
\hline & $(1)$ & $(2)$ & (3) & $(4)$ & (5) & (6) \\
\hline Discretionary revenue & $\begin{array}{c}.071 \\
(.060)\end{array}$ & $\begin{array}{c}.233 \\
(.225)\end{array}$ & $\begin{array}{c}.097^{\star} \\
(.058)\end{array}$ & $\begin{array}{c}.413 \\
(.259)\end{array}$ & $\begin{array}{c}.017 \\
(.050)\end{array}$ & $\begin{array}{c}.605^{\star *} \\
(.302)\end{array}$ \\
\hline$P$-value (Wald one-sided test) & .88 & .85 & .95 & .94 & .63 & .98 \\
\hline Fixed effects & No & Yes & No & Yes & No & Yes \\
\hline
\end{tabular}

Note. Ordinary least squares coefficients, with robust standard errors clustered at the municipality level in parentheses. All models include baseline controls and an indicator of whether the mayor had previous disciplinary sanctions at the time of the election. Fixed effects denotes models with municipality fixed effects. The sample includes municipalities where there was at least one report of vote buying. $P$-values are from a Wald one-sided test of the coefficient on discretionary revenue being positive. Municipalities $=262$; observations $=297$.

$\star p<.1$.

${ }^{* *} p<.05$.

${ }^{* * *} p<.01$. 

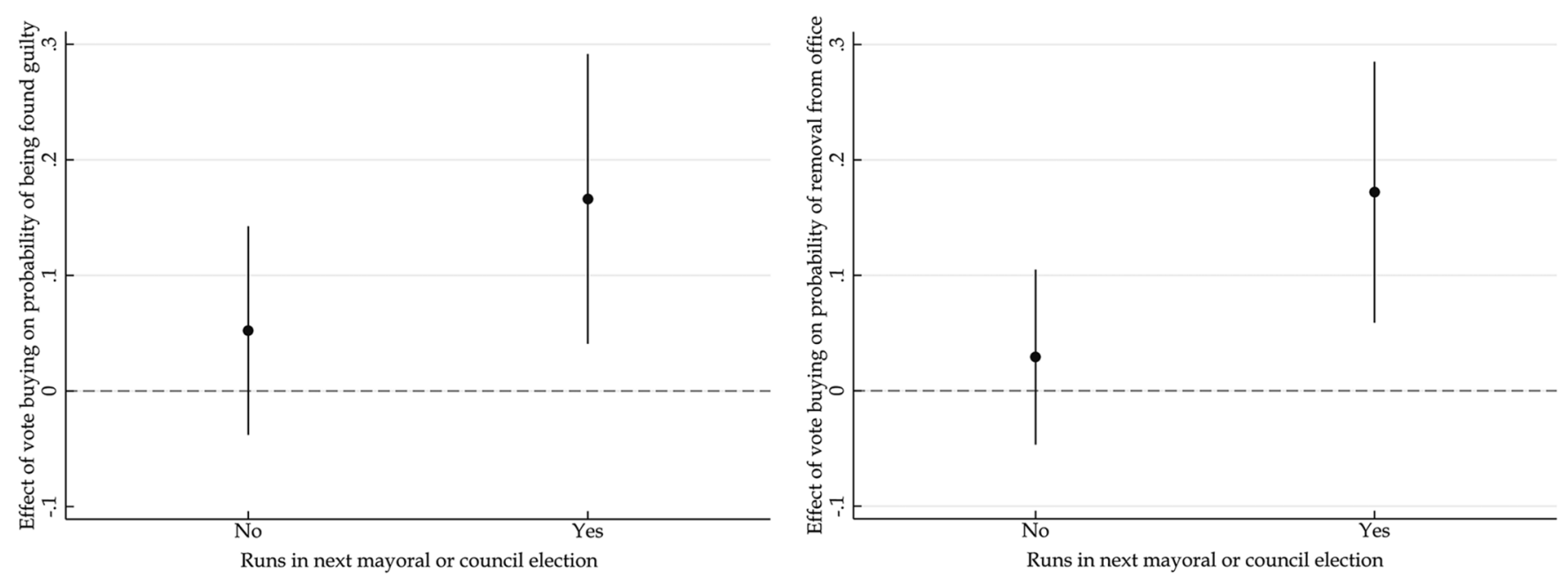

Figure 2. Sanctions, vote buying, and future participation in elections. The next mayoral or council election refers to the next election where the mayors are legally allowed to run in the same municipality.

the ones more closely represented by our theory. These are the mayors who run in the same municipality for mayor again or as a council member. Figure 2 suggests that the positive association between vote buying and sanctions is not driven by mayors uninterested in continuing their political careers. The marginal effect of vote buying on the likelihood of the mayor being found guilty and removed from office is positive and significant for those who run for mayor or for council in the same municipality. For the rest, the effect is also positive, but the point estimates are less than half that of the future runners and not significant. In the appendix, we present results in which we compare the effects of vote buying on sanctions against mayors running not only in the next election but later ones and mayors who run in races other than for council or mayor. Although these mayors might not be appealing to the same set of voters for support, we find similar results. ${ }^{18}$

An alternative to the IV approach for dealing with mismeasurement of mayors' violations of the law is to explore the relationships of interest with other measures of corruption that are not subject to the same sources of error. We use the Transparency Index built by Transparency International Colombia. We find that, consistent with proposition 1 part 1 , there is a significant negative association between vote buying and the index of transparency (higher values of the index denote less risk of corruption). Moreover, we find that this relationship is driven by the visibility component. This suggests that in places with more vote buying, the local officials do not facilitate opportunities for citizens to monitor the municipality's public finances. We also find that the relationship between the index of transparency and discretionary revenues

18. See app. E for a detailed discussion. does not appear to be positive for larger values of office. Appendix $\mathrm{F}$ provides a more detailed description of these results.

\section{CONCLUSION}

The question of how to achieve effective electoral accountability is fundamental to the study of democratic institutions. Work in this area has mostly assumed that elections' participants respect the electoral law. In such theories, voters evaluate policy platforms or use information on observed outcomes to infer which candidate will provide them with better outcomes in the future. Here we propose a different theoretical framework that is consistent with the realities of many developing democracies, by accounting for electoral irregularities.

Our theory's main prediction is that there should be a causal effect of electoral manipulation on actions taken by the incumbents against their constituents' interests. Electoral manipulation makes electoral results less responsive to policy outcomes, as the influence of citizens who vote according to those outcomes diminishes with the irregularities. Using data from Colombian regional elections, we find that an increase in reports of vote buying during an election significantly increases the probability that the winner of the election is prosecuted, found guilty, and removed from office for violating the disciplinary code of public officials. Our empirical strategies indicate that these findings are not driven by misreporting in our measures of sanctions or vote buying, by poor law enforcement capacity of certain municipalities, by administrative corruption being used to finance vote buying campaigns, or by selection of "bad politicians" who have a talent for stealing elections and public resources once in office.

The impact of electoral manipulation on outcomes is directly tied to why a more valuable office does not unconditionally 
provide incentives for incumbents to deliver what voters want. In environments where electoral manipulation is common, a more valuable office can in fact be associated with worse outcomes for society in which politicians extract more rents and double down on electoral manipulation. Using different measures of values of office, we found robust correlations that are consistent with those expectations.

These findings highlight the importance of enforcing the electoral laws before attempting to increase the compensation of elected officials or to give them more discretion over allocation of resources to increase responsiveness. During the eighties and nineties, fiscal decentralization processes complemented the adoption of direct elections at the regional level in numerous developing countries. In light of our theory, and given how common irregularities in elections are, it is not surprising that the promise of more responsive local governments that these institutional changes intended was not fulfilled.

\section{ACKNOWLEDGMENTS}

Previous versions of the article were presented at the 2017 Midwest Political Science Association meeting, the 2017 European Political Science Association meeting, the 2017 American Political Science Association meeting, the Wallis Conference on Graduate Research at the University of Rochester, the 2017 Southeast Latin American Political Behavior Mini-Conference, the London School of Economics PSPE work in progress seminar, Texas A\&M Political Science Department, and the Political Institutions and Methodology talks at Emory University. We thank the audiences and discussants in those venues and in particular Guillermo Rosas and two anonymous referees for their feedback. We also thank Lus R. Martinez for generously sharing his data on prosecutions and sanctions. All remaining errors are our own.

\section{REFERENCES}

Anduiza, Eva, Aina Gallego, and Jordi Munoz. 2013. "Turning a Blind Eye." Comparative Political Studies 46 (12): 1664-92.

Angrist, Joshua D., and Victor Lavy. 1999. “Using Maimonides' Rule to Estimate the Effect of Class Size on Scholastic Achievement." Quarterly Journal of Economics 114 (2): 533-75.

Arenas, Natalia. 2014. "La Guajira quedó en manos de los aliados de Kiko" [La Guajira was left in the hands of Kiko's allies]. La Silla Vacía, June 1.

Ashworth, Scott. 2012. "Electoral Accountability: Recent Theoretical and Empirical Work.” Annual Review of Political Science 15:183-201.

Bernard, Manin, Adam Przeworksi, and Susan Stokes. 1999. "Elections and Representation." In Manin Bernard, Adam Przeworksi, and Susan Stokes, eds., Democracy, Accountability, and Representation. London: Cambridge University Press, 29-54.

Besley, Timothy. 2004. "Paying Politicians: Theory and Evidence." Journal of the European Economic Association 2:193-215.

Besley, Timothy. 2007. Principled Agents? The Political Economy of Good Government. New York: Oxford University Press.
Brollo, Fernanda, Tommaso Nannicini, Roberto Perotti, and Guido Tabellini. 2013. "The Political Resource Curse." American Economic Review 103 (5): 1759-96.

Cantu, Francisco. 2016. "Groceries for Votes? The Electoral Returns of VoteBuying in Mexico." Prepared for delivery at the 2016 Annual Meeting of the Midwest Political Science Association.

Cattaneo, Matias D., Luke Keele, Rocío Titiunik, and Gonzalo VazquezBare. 2016. "Interpreting Regression Discontinuity Designs with Multiple Cutoffs.” Journal of Politics 78 (4): 1229-48.

Chong, Alberto, Ana L. De La O, Dean Karlan, and Leonard Wantchekon. 2015. "Does Corruption Information Inspire the Fight or Quash the Hope? A Field Experiment in Mexico on Voter Turnout, Choice, and Party Identification." Journal of Politics 77 (1): 55-71.

Cleary, Matthew, and Susan Stokes. 2006. Democracy and the Culture of Skepticism: Political Trust in Argentina and Mexico. New York: Russell Sage.

De La O, Ana Lorena. 2015. “How Corruption Breeds Clientelism.” In Jorge I. Domínguez, Kenneth F. Greene, Chappell H., Lawson, and Alejandro Moreno, eds., Mexico's Evolving Democracy: A Comparative Study of the 2012 Elections. Baltimore: Johns Hopkins University Press, 181-99.

DeVries, Catherine E., and Hector Solaz. 2017. “The Electoral Consequences of Corruption." Annual Review of Political Science 20:391-408.

El Heraldo. 2013. "Los líos que enredan a los últimos cinco gobernadores guajiros" [The troubles of the last five Guajiran governors]. El Heraldo, October 23.

Fearon, James. 1999. "Electoral Accountability and the Control of Politicians: Selecting Good Types vs. Sanctioning Poor Performance.” In Manin Bernard, Adam Przeworksi, and Susan Stokes, eds., Democracy, Accountability, and Representation. London: Cambridge University Press, 5597.

Ferejohn, John. 1986. "Incumbent Performance and Electoral Control." Public Choice 50 (1): 5-25.

Ferraz, Claudio, and Frederico Finan. 2008. "Exposing Corrupt Politicians: The Effects of Brazil's Publicly Released Audits on Electoral Outcomes." Quarterly Journal of Economics 123 (2): 703-45.

Ferraz, Claudio, and Frederico Finan. 2011. "Electoral Accountability and Corruption: Evidence from the Audits of Local Governments." American Economic Review 101 (4): 1274-311.

Fisman, Raymon, Emir Kamenica, Nikolaj A. Harmon, and Inger Munk. 2015. "Labor Supply of Politicians." Journal of the European Economic Association 13 (5): 871-905.

Gagliarducci, Stefano, and Tommaso Nannicini. 2013. "Do Better Paid Politicians Perform Better? Disentangling Incentives from Selection.” Journal of the European Economic Association 11 (2): 369-98.

García, Antonio Canchila. 2016. "Competencia de cuestionados en la Guajira" [Competition among suspects in la Guajira]. La Silla Vacía, October 23.

Gingerich, Daniel W. 2013. Political Institutions and Party-Directed Corruption in South America. Cambridge: Cambridge University Press.

Gingerich, Daniel W. 2014. "Brokered Politics in Brazil: An Empirical Analysis.” Quarterly Journal of Political Science 9 (3): 269-300.

Gingerich, Daniel W., and Luis Fernando Medina. 2013. "The Endurance and Eclipse of the Controlled Vote: A Formal Model of Vote Brokerage under the Secret Ballot." Economics and Politics 25 (3): 453-80.

Hidalgo, Daniel F., and Simeon Nichter. 2016. "Voter Buying: Shaping the Electorate through Clientelism." American Journal of Political Science 60 (2): 436-55.

Imai, Kosuke, Bethany Park, and Kenneth F. Greene. 2015. "Using the Predicted Responses from List Experiments as Explanatory Variables in Regression Models.” Political Analysis 23:180-96.

Klašnja, Marko. 2017. "Uninformed Voters and Corrupt Politicians." American Politics Research 45 (2): 256-79. 
Klašnja, Marko, and Rocío Titiunik. 2017. "The Incumbency Curse: Weak Parties, Term Limits, and Unfulfilled Accountability.” American Political Science Review 111 (1): 129-48.

Kunicová, Jana, and Susan Rose-Ackerman. 2005. "Electoral Rules and Constitutional Structures as Constraints on Corruption." British Journal of Political Science 35 (4): 536-606.

Larreguy, Horacio, John Marshall, and Pablo Querubin. 2016. "Parties, Brokers, and Voter Mobilization: How Turnout Buying Depends upon the Party's Capacity to Monitor Brokers." American Political Science Review 110 (1): 160-79.

Martínez, Luis R. 2016. "Sources of Revenue and Government Performance: Evidence from Colombia.” Social Science Research Network. https:// ssrn.com/abstract $=3273001$.

Micozzi, Juan Pablo. 2014. "From House to Home: Strategic Bill Drafting in Multilevel Systems with Non-static Ambition." Journal of Legislative Studies 20 (3): 265-84.

Nyblade, Benjamin, and Steven R. Reed. 2008. "Who Cheats? Who Loots? Political Competition and Corruption in Japan, 1947-1993." American Journal of Political Science 52 (4): 926-41.

Persson, Torsten, and Guido Tabellini. 2000. Political Economics: Explaining Economic Policy. Cambridge, MA: MIT Press.

Rueda, Miguel R. 2015. "Buying Votes with Imperfect Local Knowledge and a Secret Ballot." Journal of Theoretical Politics 27 (3): 428-56.
Rueda, Miguel R. 2017. “Small Aggregates, Big Manipulation: Vote Buying Enforcement and Collective Monitoring." American Journal of Political Science 61 (1): 163-77.

Semana. 2013. "El 'dossier' delictivo de Kiko Gomez" [The criminal dossier of Kiko Gomez]. Semana, October 19.

Simpser, Alberto. 2012. "Does Electoral Manipulation Discourage Voter Turnout? Evidence from Mexico.” Journal of Politics 74 (3): 782-95.

Singer, Matthew. 2009. "Buying Voters with Dirty Money: The Relationship between Clientelism and Corruption." Prepared for delivery at the 2009 Annual Meeting of the American Political Science Association.

Smith, Alastair, and Bruce Bueno de Mesquita. 2012. "Contingent Prize Allocation and Pivotal Voting." British Journal of Political Science 42 (2): 371-92.

Vicente, Pedro C. 2013. "Is Vote Buying Effective? Evidence from a Field Experiment in West Africa.” Economic Journal 124 (574): F356F387.

Weitz-Shapiro, Rebecca, and Matthew S. Winters. 2016. "Can Citizens Discern? Information Credibility, Political Sophistication, and the Punishment of Corruption in Brazil." Journal of Politics 79 (1): 60-74.

Winters, Matthew S., and Rebecca Weitz-Shapiro. 2013. "Lacking Information or Condoning Corruption: When Do Voters Support Corrupt Politicians?" Comparative Politics 45 (4): 418-36. 